\author{
Asian Journal of \\ Medical and Biological Research \\ ISSN 2411-4472 (Print) 2412-5571 (Online) \\ www.ebupress.com/journal/ajmbr
}

\title{
Article \\ Food intake pattern and nutritional status of hemodialytic patients
}

\author{
Mousumi Akter ${ }^{1}$ and Farzana Alam ${ }^{2 *}$ \\ ${ }^{1}$ Food and Nutrition Department, Khulna City Corporation Women's College (affiliated to Khulna University), \\ Khulna, Bangladesh \\ ${ }^{2}$ Department of Genetic Engineering and Biotechnology, Jagannath University, Dhaka-1100, Bangladesh
}

"Corresponding author: Farzana Alam, Assistant Professor, Department of Genetic Engineering and Biotechnology, Jagannath University, Dhaka-1100, Bangladesh. Email: faprova@yahoo.com

Received: 25 November 2020/Accepted: 28 December 2020/ Published: 31 December 2020

\begin{abstract}
The incidence of renal disease is increasing at an alarming rate in Bangladesh. Malnutrition is directly correlated with the prevalence with these diseases. A total of 120 dialysis patients from both sexes having mean age 45 \pm 13 . 79 years undergoing hemodialysis were enrolled for the study in Khulna city, Bangladesh. Information regarding disease history and associated co morbidities were collected from patient's files. The personal information, prevalent vices, exercise behavior, dietary modifications and clinical and health status of the patients were recorded by using pre-tested questionnaire. Etiology of the chronic renal disease, complications and biochemical parameters were documented from the case files. Renal failure was more prevalent among male than in female. Diabetes mellitus (31.67\%) were the most common etiology for chronic renal failure. Pallor of eyes was the most prevailing sign and the most common symptoms are breathlessness (98\%), oliguria (88\%), anorexia (67\%) and nausea (60\%). Nutritional status was assessed by anthropometric measurements using body mass index (BMI), mid arm circumference (MAC) and waist hip ratio (WHR). According to BMI, 43\% male are grouped in normal category whereas majority of females (52\%) are underweight with no overweight female respondents. $80 \%$ male had low adequacy of energy whereas all the female patients had adequacy of energy, carbohydrate and protein on low level. Dietary data was obtained by using 24-hour dietary recall and food frequency questionnaire. Actual intake of calories, protein, fats and minerals was lower than the recommended intake for hemodialysis patients. More than 50 percent of patient on hemodialysis were at risk of malnutrition. Around 32\% respondents included fruits as per doctor's advice whereas water and salted foods were restricted to three fourth of patients to protect kidney. Proper assessment of nutritional status, nutritional management and dietary modification can play a central role in preventing malnutrition of hemodialysis patients.
\end{abstract}

Keywords: nutritional status; dietary modification; chronic kidney diseases; hemodialysis

\section{Introduction}

Chronic kidney disease (CKD) is a major public health problem worldwide due to increase incidence of hypertension and diabetes. CKD patients are at high risk for progression to the end stage renal disease (ESRD) and presently the predicted number of ESRD patients is estimated to be over 2 million worldwide (Hasan et al., 2013). Chronic kidney disease is a progressive loss of kidney functions, defined as kidney damage or an estimated glomerular flirtation rate (GFR) of less than $60 \mathrm{ml} / \mathrm{min}$. It is a major public health problem which affects over 500 million people worldwide (Hajira et al., 2013). The most common indicators of kidney damage are proteins in the urine (proteinuria or albuminuria), blood in the urine (haematuria) and raised levels of urea or creatinine (a waste product of protein metabolism) in the blood. There are five stages of kidney diseases that are classified by glomerular filtration rate (GFR). GFR is a measurement of the amount of blood the kidneys clear of waste products in one minute (Salem and Harvie, 2016). 
Dialysis treatment is used for both very sick patients who have suddenly lost their kidney function (acute renal failure) and for quite stable patients who have permanently lost their kidney function (end stage renal failure) (Gillian Field, 2007). Hemodialysis is the most common method used to treat advanced and permanent kidney failure. Hemodialysis involves the creation of an extracorporeal circuit. Blood is taken from the circulation to a dialyzer for cleansing and then returned to the patient's body (Anand et al., 2014).

Malnutrition is a common consequence of patients' inability to meet their requirements as well as a strong predictor of both morbidity and mortality in Hemodialysis patients. $35 \mathrm{kcal} / \mathrm{kg}$ IBW/day energy intakes is generally advised to the Hemodialysis patient aiming for overall nutritional adequacy which includes $1-1.2 \mathrm{~g} / \mathrm{kg}$ IBW/day dietary protein non-catabolic patients, $1000-1400 \mathrm{mg} /$ day for phosphorus, $1800-2500 \mathrm{mg} / \mathrm{day}$ for sodium with a fluid allowance of $500 \mathrm{ml}$ plus a volume equal to daily urine output (James and Jackson, 2002).

Anthropometry is the most effective method to assess the protein-energy nutritional status of patients with chronic kidney disease. This method is also useful for assessing the patient's amount of adiposity and lean mass, and comprises height, body weight, percent of standard body weight (the patient's current weight expressed as a percentage of ideal weight), body mass index (BMI), skinfold thickness, arm circumference (AC), and arm muscle area (AMA) (Oliveria et al., 2010). Several anthropometric measurements is done after finishing of the hemodialysis session and the body mass index (BMI) is computed as the ratio between end-hemodialysis body weight in $\mathrm{kg}$ and the square of height in meters $(\mathrm{kg} / \mathrm{m} 2)$ (Chen et al., 2013). Additionally, serum proteins particularly albumin indicates the key biochemical parameters for the nutritional status assessment. However, it is important to note that abnormalities in serum protein synthesis may not be directly related to change in nutritional status. In general condition, serum albumin levels have been shown to decrease in conditions of fluid volume overload, with the dilution of serum albumin concentration due to an increase of extra cellular fluid, which is prevalent in CKD patients. Other serum protein like transferrin and pre albumin has also been utilized for assessment of nutritional status in CKD. In particular, transferrin can be influenced by iron status and pre albumin, which is usually excreted by the kidneys and may change prospectively in response to a change in kidney function, not necessarily nutritional status (Katrina Louise Campbell, 2007)

Protein energy malnutrition is quite common in Hemodialysis patients and directly associated with increased morbidity and mortality, reduced physical function, and poor quality of life. Two types of malnutrition are common in the dialysis population: defective nutrition due to a poor nutrients intake (the so-called true malnutrition) and abnormal body composition with a reduction of somatic and visceral protein pool, as a result of a catabolic condition linked to a pro-inflammatory state. In fact, malnutrition and inflammation often coexist in Hemodialysis patients are associated with accelerated atherosclerosis: this condition is called malnutritioninflammation-atherosclerosis (MIA) syndrome. This condition negatively affects the clinical outcome of hemodialysis population, increasing cardiovascular disease and events (Cupisti et al., 2010).

As Hemodialysis is directly linked to nutritional intake and the nutritional requirements of the patient, this study was to assess the dietary habits and nutritional status of hemodialysis patients, aiming to detect changes of actual daily nutrient intake that they are practicing in respect to normal subjects and then compare with guideline recommendations to assess the prevalence of signs of malnutrition.

\section{Materials and Methods}

\subsection{Study site}

The study was conducted at the Dialysis unit of Gazi Medical College Hospital, ISK Foundation-Afzalia Estate Kidney Center and Sheikh Abu Nasar Hospital in Khulna City. Among these, Sheikh Abu Nasar Hospital is one of the biggest dialysis center in Khulna City with 20 HD machines and more than 40 patients can be dialyzed everyday in two shifts and Most of the data were collected from that hospitals.

\subsection{Study period}

The survey was conducted from July to December 2014. Initial months were taken for selection of topic, objective setting, followed by literature review, questionnaire development, pre-testing for data collection, data analysis, data entry and submission of report.

\subsection{Selection of sample}

Following the Purposive sampling method, one hundred twenty chronic kidney failure patients maintaining Hemodialysis were selected from dialysis unit of Gazi Medical College Hospital, ISK Foundation and Afzalia Estate Kidney Center and Sheikh Abu Nasar Hospital in Khulna City. 


\subsection{Tools development}

A detailed questionnaire was developed, to raise information on various aspects related to renal patients including demographic profile, clinical and health status, symptoms at the onset of disease, existing signs, etiology of renal disease, medications and supplementations being used, complications seen, life style factors and nutritional profile with respect to anthropometry, dietary intake and biochemical parameters. The questionnaire was structured and modified based on the suggestions of the experts. Further, the developed questionnaire was pre-tested on renal patients at Gazi Medical College Hospital and required changes were made before the final survey has started.

\subsection{Data collection}

The questionnaire was consisted with three segments. The first part containing information on sociodemographic and economic aspects of chronic renal failure patients included age, gender, education, occupation, monthly income of family, family size, number of earning members, activity pattern of respondent and marital status was collected by interviewing the respondent. The Clinical and health status of dialysis patients were included in the second part. Information on kidney disease and others disorders, date of commencement of maintenance hemodialysis, medication and supplementation were included in this section. Additionally, Present prevalent vices in subjects such as smoking, betel nut, and tobacco chewing were recorded. An information on exercise habits with special reference to type, regularity, benefits observed and who advised alike were collected. Anthropometric measurements viz., height $(\mathrm{cm})$, weight $(\mathrm{kg})$, waist $(\mathrm{cm})$, hip $(\mathrm{cm})$ and mid arm circumferences $(\mathrm{cm})$ were recorded as per the guidelines according WHO criteria. Body Mass Index (BMI) was computed using the formula given by Garrow (1987) to classify the individual as normal, obese or underweight where the abdominal obesity was assessed by waist/hip ratio. MAC (Mid-arm circumference) was measured by using a measuring tape in centimeters. At the dry weight, patient's right or non- access arm was bent at the elbow at $90^{\circ}$ angle, palm up, to locate the arm's midpoint on posterior side of the arm. With the same arm hanging loosely by side, the tape was positioned at previously marked midpoint of upper arm and the circumference was obtained. For dietary assessment, each patient was interviewed for the consumption of food and beverages using 24 hour recall method and food frequency questionnaire. The responses were recorded on the questionnaires. The portion Sizes of foods consumed by each patient were converted into percent of carbohydrates, fats proteins and kcal. On the last part of survey, biochemical parameters were documented from the case files of each patient maintained in the hospital. For dialysis patients, biochemical profile recorded at the time of first dialysis and the present status were documented. Biochemical profile included serum albumin, total protein, creatinine, urea, sodium, potassium, calcium, phosphorus and lipid profile including total cholesterol and triglycerides.

\subsection{Statistical analysis}

The data were compiled from the questionnaire and fed into the Microsoft excel version 2007 and converted into SPSS-20 for statistical analysis. Descriptive statistics were run to check the distribution of the data and to check for errors that had been made in the data entry.

\section{Results}

\subsection{Socio demographic characteristics}

Among 120 patients, Chronic Kidney Diseases is more prevalent in male (75.8\%) than female (24.2\%). Majority were falling in the age group of 41-60 years (50\%) followed by $20-40$ years $(38.33 \%)$ and very few were more than 60 years (11.67\%). Most of the patients had primary school level education (38.3\%) and only $22.5 \%$ have college level education. Almost $98 \%$ were non-vegetarian and about $2 \%$ were vegetarian. Among chronic renal failure patients higher percentage had a medium sized family $(71.7 \%)$ followed by small $(18.3 \%)$ and large sized family (10\%). 35\% respondents' monthly income had five thousand to ten thousand followed by (38\%) respondents had ten thousand to twenty thousand. Very few $(19.2 \%)$ had twenty thousand to thirty thousand and only $(8.3 \%)$ respondent's monthly income had over thirty thousand. The demographic profile of hemodialytic patients is presented in Table 1.

\subsection{Life style pattern}

Focusing on life style pattern among respondents, about $68.3 \%$ had no vices at the time of investigation. However, Tobacco and betelnut chewing was the most common vice found dialytic patients $27.5 \%$ whereas smoking only (4.2\%). These vices were present prior to the onset of disease, but were still prevailing after the 
onset of disease (Table 2). Higher percentage $(52.5 \%)$ of dialytics exercised regularly and most common exercise was walking and rest of them (47.5\%) were not regular in the exercise.

\subsection{Clinical and health status of CKD patients}

The majority of hemodialytic patients $(91.7 \%)$ suffered from various disorders such as hypertension, diabetic. Very few patients $(8.3 \%$ ) had no disorder prior to the onset of kidney disease. More than fifty percent of patients were diagnosed for the renal disease between 24 months and had been suffering from this disease from 25 to 48 months (20\%). About (9.2\%) were suffering from kidney disease for the last 49 to 72 months $(9.2 \%)$ and very few had it more than 72 months $(1.7 \%)$. In the present study, it was observed that the most common cause of chronic renal failure was diabetes (31.67\%), only hypertension (10\%) and both(28.33\%)and others (30\%) which include chronic glomerulonephritis, Chronic pyelonephritis, and familial and cystic renal disease, between these chronic glomerulonephritis percentage was high than others.

Breathlessness were the most common symptoms as $81.7 \%$ people had it, followed by oliguria and anorexia (73.3\% and $66.7 \%$, respectively). Headache, nausea, nocturia and vomiting were prevailing in almost 50 per cent of the Respondents. Very few subjects suffered from hematuria (10.8\%) followed by loss of consciousness $(22.5 \%)$ and convulsions (26.7\%). Prevailing clinical signs of the respondents at the time of investigation is presented in table (3). It was observed that clinical signs such as pallor of eyes and nails were common in all the subjects undergoing dialysis (100\%) followed by edema (91.7\%) and swollen joints $(52.5 \%)$. Very few respondents $(15.8 \%)$ had poor wound healing.

\subsubsection{Clinical characteristics}

In the present study BMI, MAC, WHR were used to assess the nutritional status of the patients. In all respondents, majority of males were normal $(42.86 \%)$ and equal number were grouped under underweight and overweight categories (28.57\%).Among females normal categories (48.28\%) followed by underweight categories (51.72\%) and none was observed to be overweight. With respect to waist to hip ratio, Majority of the male patients were normal (61.54\%) with few (38.46\%) had abdominal obesity. Conversely among female about $(27.6 \%)$ belonged to normal category and $72.41 \%$ belonged to obese category. The table 4 presents with the gender wise classification of patients based on MAC. Most male patients (57.14\%) were standard categories followed by $38.46 \%$ belonged to under categories and very few (4.4\%) over categories. Conversely only $13.8 \%$ women were in standard categories and most of the female (86.2\%) belonged to under categories.

\subsection{Dietary assessment}

Majority of dialytic male had low adequacy of energy, carbohydrate, protein and fat $(80.22 \%, 47.25 \%, 90.11 \%$, \& $61.54 \%$ respectively). About 10 in 100 male had adequate energy, carbohydrate, protein and $25.27 \%$ male had adequate fat intake. Conversely all the female respondents had low energy, carbohydrate and protein intake pattern. Very few male had high energy, carbohydrate and fat $(9.89 \%, 9.89 \%$ \& $13.18 \%$ respectively) and surprisingly no male did not consume high protein. Most of the female $75.86 \%$ had low energy and only $24.14 \%$ had adequate fat. All female patients had low adequacy of energy and protein.

\subsection{Dietary modification}

It was observed higher percentage (31.7\%) of dialytic patients included fruits like apple, guava and pineapple and inclusion of leached vegetables $(8.3 \%)$. About (20\%) of respondents consumed chicken and fish as a special foods in the diet. However, the reasons quoted for including the special foods was due to the doctor's advice. Inclusion of fruits was due to the low potassium content. The vegetables were leached by boiling in water and discarding the water to reduce the potassium content. Chicken and fish were eaten to increase the protein content of the diet. Regarding food restriction, 6 out of 10 patients did not practice any restriction for food items. The remaining patients were restricted for excessive water intake (40\%) and salty food items $(24.7 \%)$ respectively. The reasons given for restricting water and salty food items were to protect kidney and to decrease the sodium level. The foods avoided by the patients were coconut water $(80 \%)$, sweet items $(31.67 \%)$, and banana $(28.33 \%)$, respectively. Sweet items were avoided as they raised blood sugar in diabetic renal patients and coconut water and banana were avoided as they raised the potassium levels in the blood. 
Table 1. Demographic characteristics of population $(n=120)$.

\begin{tabular}{|c|c|c|c|c|c|c|c|c|c|c|c|}
\hline \multicolumn{2}{|r|}{ Age } & \multicolumn{2}{|c|}{ Gender } & \multicolumn{2}{|c|}{ Family size } & \multicolumn{2}{|c|}{ Food habit } & \multicolumn{2}{|c|}{ Education } & \multicolumn{2}{|c|}{$\begin{array}{c}\text { Monthly income } \\
\text { (tk) }\end{array}$} \\
\hline $20-40$ & $\begin{array}{c}46 \\
(38.33 \%)\end{array}$ & Male & $\begin{array}{c}91 \\
(75.8 \%)\end{array}$ & $\begin{array}{c}\text { Small } \\
(<4)\end{array}$ & $\begin{array}{c}22 \\
(18.3 \%)\end{array}$ & \begin{tabular}{|c|} 
Non- \\
Vegetarian
\end{tabular} & $\begin{array}{c}118 \\
(98.3 \%)\end{array}$ & Illiterate & $\begin{array}{c}13 \\
(10.83 \%)\end{array}$ & $\begin{array}{l}5000- \\
10000\end{array}$ & $\begin{array}{c}42 \\
(35 \%)\end{array}$ \\
\hline $41-60$ & $\begin{array}{c}60 \\
(50.00 \%) \\
\end{array}$ & Female & $\begin{array}{c}29 \\
(24.2 \%) \\
\end{array}$ & $\begin{array}{c}\text { Medium } \\
(4-8)\end{array}$ & $\begin{array}{c}86 \\
(71.7 \%)\end{array}$ & Vegetarian & $\begin{array}{c}2 \\
(1.7 \%) \\
\end{array}$ & $\begin{array}{c}\text { Primary } \\
\text { School }\end{array}$ & $\begin{array}{c}46 \\
(38.33 \%)\end{array}$ & $\begin{array}{l}10000- \\
20000\end{array}$ & $\begin{array}{c}45 \\
(37.5 \%)\end{array}$ \\
\hline$>60$ & $\begin{array}{c}14 \\
(11.67 \%)\end{array}$ & - & - & $\begin{array}{c}\text { Large } \\
(>8)\end{array}$ & $\begin{array}{c}12 \\
(10.0 \%)\end{array}$ & - & - & $\begin{array}{c}\text { High } \\
\text { School }\end{array}$ & $\begin{array}{c}34 \\
(28.33 \%)\end{array}$ & $\begin{array}{c}20000- \\
30000\end{array}$ & $\begin{array}{c}23 \\
(19.2 \%)\end{array}$ \\
\hline- & - & - & - & - & - & - & - & College & $\begin{array}{c}27 \\
(22.5 \%) \\
\end{array}$ & $>30000$ & $\begin{array}{c}10 \\
(8.3 \%) \\
\end{array}$ \\
\hline
\end{tabular}

Table 2. Distribution according to Life Style among population ( $N=120)$.

\begin{tabular}{|l|l|l|l|}
\hline \multicolumn{2}{|c|}{ Exercising Habit } & \multicolumn{2}{c|}{ Vices Practicing } \\
\hline Yes & $63(52.5 \%)$ & No Vices & $82(68.3 \%)$ \\
\hline No & $57(47.5 \%)$ & Smoking & $5(4.2 \%)$ \\
\hline & & Betel Nut and Tobacco Chewing & $33(27.5 \%)$ \\
\hline
\end{tabular}

Table 3. Distribution of respondents according to their clinical and health status.

\begin{tabular}{|c|c|c|c|c|c|c|c|c|c|}
\hline \multicolumn{2}{|c|}{$\begin{array}{l}\text { Disorder before the onset } \\
\text { of kidney disease }\end{array}$} & \multicolumn{2}{|c|}{$\begin{array}{l}\text { Onset of kidney } \\
\text { disease (in month) }\end{array}$} & \multicolumn{4}{|c|}{$\begin{array}{l}\text { Symptoms at the time of onset of Kidney } \\
\text { Disease }\end{array}$} & \multicolumn{2}{|c|}{$\begin{array}{l}\text { Clinical Signs at the } \\
\text { time of Investigation }\end{array}$} \\
\hline $\begin{array}{l}\text { Clinical } \\
\text { Features }\end{array}$ & $\begin{array}{l}\text { Frequency } \\
(\%)\end{array}$ & $\begin{array}{l}\text { Clinical } \\
\text { Features }\end{array}$ & $\begin{array}{l}\text { Frequency } \\
(\%)\end{array}$ & $\begin{array}{l}\text { Clinical } \\
\text { Features }\end{array}$ & $\begin{array}{l}\text { Frequency } \\
(\%)\end{array}$ & $\begin{array}{l}\text { Clinical } \\
\text { Features }\end{array}$ & $\begin{array}{l}\text { Frequency } \\
(\%)\end{array}$ & $\begin{array}{l}\text { Clinical } \\
\text { Features }\end{array}$ & $\begin{array}{l}\text { Frequency } \\
(\%)\end{array}$ \\
\hline Present & $110(91.7)$ & $1-24$ & $83(69.2)$ & Anorexia & $80(66.7)$ & Nausea & $72(60.0)$ & $\begin{array}{l}\text { Pallor of } \\
\text { Eyes }\end{array}$ & $120(100)$ \\
\hline Absent & $10(8.3)$ & $25-48$ & $24(20)$ & Breathlessness & 98 (81.7) & Nocturia & $59(49.2)$ & $\begin{array}{l}\text { Pallor of } \\
\text { Nails }\end{array}$ & $120(100)$ \\
\hline Etiology & & $49-72$ & $11(9.2)$ & Convulsions & $32(26.7)$ & Oliguria & $88(73.3)$ & $\begin{array}{l}\text { Swollen } \\
\text { Joints }\end{array}$ & $63(52.5)$ \\
\hline $\begin{array}{l}\text { Diabetes } \\
\text { Mellitus }\end{array}$ & 38 (31.67) & $>72$ & $2(1.7)$ & $\begin{array}{l}\text { Frequent } \\
\text { Urination }\end{array}$ & $50(41.7)$ & Oliguria & $88(73.3)$ & Edema & $110(91.7)$ \\
\hline Hypertension & $12(10)$ & - & - & Headache & $67(55.8)$ & Vomiting & $69(57.5)$ & $\begin{array}{l}\text { Poor } \\
\text { wound } \\
\text { Healing }\end{array}$ & $19(15.8)$ \\
\hline $\begin{array}{l}\text { Diabetes } \\
\text { Mellitus \& } \\
\text { Hypertension }\end{array}$ & $34(28.33)$ & - & - & Hematuria & $13(10.8)$ & $\begin{array}{l}\text { Any } \\
\text { Other* }\end{array}$ & $45(37.5)$ & - & - \\
\hline Others & $36(30)$ & - & - & $\begin{array}{l}\text { Loss of } \\
\text { Consciousness }\end{array}$ & $27(22.5)$ & - & - & - & - \\
\hline
\end{tabular}

Table 4. Clinical characteristics of CKD patients $(n=120)$.

\begin{tabular}{|l|l|l|l|l|l|l|l|l|}
\hline \multirow{2}{*}{ Respondents } & \multicolumn{3}{|c|}{ Body Mass Index } & \multicolumn{2}{|l|}{ Waist to Hip Ratio* } & \multicolumn{3}{l|}{ Mid Arm Circumference (MAC) } \\
\cline { 2 - 9 } & $\begin{array}{l}\text { Under } \\
\text { Weight } \\
(\mathbf{1 8 . 5 )}\end{array}$ & $\begin{array}{l}\text { Normal } \\
\mathbf{( 1 8 . 5 -}\end{array}$ & $\begin{array}{l}\text { Overweight } \\
\mathbf{2 4 . 9 9 )}\end{array}$ & Normal & Obese & Under & $\begin{array}{l}\text { Standard } \\
\text { Range }\end{array}$ & over \\
\hline Male (91) & 26 & 39 & 26 & 56 & 35 & 35 & 52 & 4 \\
& $(28.57 \%)$ & $(42.86 \%)$ & $(28.57 \%)$ & $(61.54 \%)$ & $(38.46 \%)$ & $(38.46 \%)$ & $(57.14 \%)$ & $(4.4 \%)$ \\
\hline Female (29) & 15 & 14 & - & 8 & 21 & 25 & 4 & 0 \\
& $(51.72 \%)$ & $(48.28 \%)$ & & $(27.6 \%)$ & $(72.41 \%)$ & $(86.2 \%)$ & $(13.8 \%)$ & \\
\hline
\end{tabular}


Table 5. Distribution of respondents according to nutrients uptake (n=120).

\begin{tabular}{|l|l|l|l|l|}
\hline Nutrients & & \multicolumn{3}{|c|}{ Frequency of Adequacy (\%) } \\
\hline & Gender & Low & Adequate & High \\
\hline Energy (Kcal) & Male $(\mathrm{n}=91)$ & $73(80.22)$ & $9(9.89)$ & $9(9.89)$ \\
& Female (n=29) & $29(100)$ & - & - \\
\hline Carbohydrate $(\mathrm{g})$ & Male $(\mathrm{n}=91)$ & $43(47.25)$ & $39(42.86)$ & $9(9.89)$ \\
& Female (n=29) & $29(100)$ & - & - \\
\hline Protein (g) & Male (n=91) & $82(90.11)$ & $9(9.89)$ & - \\
& Female (n=29) & $29(100)$ & - & - \\
\hline Fat $(\mathrm{g})$ & Male (n=91) & $56(61.54)$ & $23(25.27)$ & $12(13.18)$ \\
& Female (n=29) & $22(75.86)$ & $7(24.14)$ & - \\
\hline
\end{tabular}

Table 6. Dietary modification by CKD patients.

\begin{tabular}{|l|l|l|}
\hline Dietary Modification & Frequency $\mathbf{\%})$ & Reason for inclusion and restriction \\
\hline Food Specially included & \multicolumn{2}{|l|}{} \\
\hline Fruit like apple, guava, and pineapple & $38(31.7)$ & Doctor's Advice and they were Low Potassium Fruits \\
\hline Leached Vegetables & $10(8.3)$ & To Reduce Potassium Content \\
\hline Chicken and Fish & $24(20.0)$ & To Raise Protein Level \\
\hline Restricted foods & $72(60.0)$ & \\
\hline No Restriction & $48(40.0)$ & To protect Kidney in Body \\
\hline Water & $29(24.17)$ & Raises Serum Sodium Level. \\
\hline Salty Food items & \multicolumn{2}{|l}{} \\
\hline Avoided foods & $24(20.0)$ & Raises potassium Level \\
\hline No Avoidance & $96(80.0)$ & Raises potassium Level \\
\hline Coconut Water & $34(28.33)$ & Raises Blood Sugar Level \\
\hline Fruits like Banana & $38(31.67)$ & \\
\hline Sweets &
\end{tabular}

\section{Discussion}

Chronic kidney disease is a major public health and clinical problem throughout the world including Bangladesh. Malnutrition is a relatively common problem in chronic renal failure which can be secondary to poor nutrient intake, to increased losses or to an increase in protein catabolism.

In the present study, it was observed that the most common cause of chronic renal failure in dialytic was diabetes $(31.67 \%)$, followed by hypertension. Diabetes, hypertesion, heart diseases have already been identified as the major causes of Chronic Kidney Diseases by Prakash et al. (2004), Gillani et al. (2013); Khadija and Evelyn (2012). Vijya et al.(2019) found (28.5\%) had diabetes mellitus and (86\%) had hypertension, and these two major risk factors might have contributed to the development of ESRD in their patients. Edema (91.7\%) followed by breathlessness $(81.7 \%)$, oliguria $(73.3 \%)$ and anorexia $(66.7 \%)$ are the main nonspecefic symptoms for CKD patients. The cause for edema and oliguria may be due to impaired ability to excrete because of defective tubular function resulting in an overt expansion of the plasma and extracellular fluid volumes and edema. Shortness of breath may indicate congestive heart failure, anaemia or metabolic acidosis. Anorexia points to advanced uremia. Quality of life can be improved and renal disease can be prevented with certain modifications in the life style such as in food intake, regular exercise, regular intake of prescribed medicine as well as avoiding some restricted foods containing high potassium and high biological value protein.

In this study, most of the female (51.72\%) patients were malnourished and all patients with severe malnutrition were women. Fatemeh et al. (2014) also stated that, men had no malnutrition while all women had some degrees of malnutrition. Khadija \& Evelyn (2012) also reported that a significantly higher percentage of females $(66.4 \%, n=71)$ were malnourished when compared with males $(46.3 \%, n=75)$. Women had lower BMI, thicker skin folds and smaller MAMC when compared with men. The lower anthropometric and biochemical values in dialytic patients due to lower intake of food because of anorexia which is caused by uremic toxicity, medicinal intake, emotional depression, intercurrent illness and the dialysis process. Patients are often starved in preparation for diagnostic procedures or because of gastrointestinal disorder.

The low serum albumin and total protein levels are common for CRF patient's .But in our study the dialytics consumed high biological value proteins. This may be the reason for better protein status in terms of serum albumin and total protein. But still the values of dialytic patients were not comparable to the normal values; this may be due to the loss of amino acids in the dialysis process. The low values for the hemoglobin in both the 
groups (male and female) in the present study may be due to the progress in the kidney disease leading to decreased production of erythropoietin hormone. Iron deficiency also occurs when intestinal iron absorption is impaired and substantial blood loss occurs in CRF patients. Frequent blood collections for laboratory measurements in case of CRF patients, the residual blood volume in the dialyzer may be the causes for this.

Both male and female respondents belonged to underweight group indicating malnutrition in the present study; this may be due to the constant restriction of food due to monotony of diets, low food intake in terms of energy and proteins, mental depression and anorexia. The reasons for malnutrition may be complex and related to loss of nutrients during dialysis, altered metabolic requirement.

Nutritional assessment is the first step in the treatment of malnutrition. There is a great need to assess the nutritional status of hemodialysis patients to pay the way for early nutrition intervention and nutrition education to improve their health status for well-being. Adequate dialysis improves appetite with subsequent increase of protein and calorie intake leading to better nutritional status of dialytics.

Patients on Hemodialysis usually have poor dietary habits along with loss of appetite, alteration of sensory and taste perception is common among Hemodialysis (HD) patients. Nutritional therapy when properly applied reduce progressive protein depletion and malnutrition and these patients are better off nutritionally when compared to their counterparts of comparable severity on dialysis. Several observational studies showed, Hemodialysis patients daily energy intake (DEI) should be $30-35 \mathrm{Kcal} / \mathrm{kg} / \mathrm{d}$, Dietary protein intake (DPI) should be $1.2 \mathrm{~g} / \mathrm{kg} / \mathrm{d}$ (at least $50 \%$ should be high biological value), Fat should be $25-35 \%$ of total energy intake and carbohydrate should be complex.

According to this study dialytic patients modified in their diet due to physicians' advice and patients acquired knowledge regarding certain food items. These modifications in the diet are highly useful in the management of the renal disease and further prevention of complications. Unrestricted sodium intake accentuates hypertension and precipitate congestive heart failure. So in the present study 1-3 g sodium and upto $2000 \mathrm{ml}$ water was suggested depending on urine output. Therefore, in the present study about 30-35 Kcal of energy of ideal body weight and 1.2 grams of protein were prescribed to the dialytics. High biological value foods such as egg, chicken and fish in non-vegetarians and soybeans and milk in vegetarian were prescribed. The carbohydrate intake prescribed was 50-60 per cent of the total energy. The simple carbohydrates such as sugar, sweets like halwas prepared from papaya, carrot, bottlegourd was included to increase the intake of sugar and glucose in the diet. The quantities of fats and oils included were higher since higher energy was coming from non-protein sources. So the medium chain triglycerides were prescribed to these subjects to improve the palatability and assimilation.

\section{Conclusions}

From the study it is proved that dialysis does not cure the kidney disease, but it can be a life saving treatment also it greatly improves our quality of life. Through this study it is said that in stable dialysis patients, abnormalities of nutritional parameters are less prevalent than expected by analysis of dietary food intake, and that the majority of patients reported a lower than recommended energy and protein intake. Age is the best predictor of energy and protein intake in the dialysis patients who ate less than normal people, but no difference emerged when energy and protein intakes were normalized for body weight. These results recall the attention for individual dietetic counseling in HD patients, and also for a critical re-evaluation of their dietary protein and energy requirements. This study also showed that proper Nutritional education and counseling for patients with renal disease plays a major role in the preservation of renal function and the overall wellbeing of the renal patient.

\section{Conflict of interest}

None to declare.

\section{References}

Fatemeh E, T Khoddad and L Esmaeili, 2014. Evaluation of malnutrition and its association with biochemical parameters in patients with end stage renal disease undergoing hemodialysis using subjective global assessment. Nephrourol Mon., 6: e16385.

Gillani SW and A Wulandari, 2013. Study of the Risk Factors on the Patient with Kidney Disorders at the Hospital University Sains Malaysia, Innovations in Pharmaceuticals and Pharmacotherapy, 1: 39-43

Hajira B, M Samiullah and KR Chawla, 2013. Nutritional Status Assessment of Hemodialysis Patients At Rehman Medical Institute Peshawar. ARPN Journal of Agricultural and Biological Science, PP: 329 
Hasan MJ, MA Kashem, MH Rahman, R Qudduhus, M Rahman, A Sharmeen and N Islam, 2013. Prevalence of Chronic Kidney Disease (CKD) and identification of Association Risk Factors among Rural Population by Mass Screening. Community Based Medical Journal, 1: 20-26.

James and H Jackson, 2002. European Guidelines for the Nutritional Care of Adult Renal Patients, pp. 2-9.

Katrina Louise Campbell, 2007. Nutrition Management in pre-dialysis Chronic Kidney Disease.

Khadija A and EB Enrione, 2012. Malnutrition is prevalent among hemodialysis patients in Jeddah, Saudi Arabia, Renal Data from The Arab World, 23: 598-608

Oliveira CMC, M Kubrusly, MSM Rosa, CAB Silva and N Valzimeire, 2010. Malnutrition in Chronic Kidney Failure: What is the best diagnostic method to assess? Jornal Brasileiro de Nefrologia, 32: 55-68

Praksh S, DP Pande, S Sharma, D Sharma, CS BAL and H Kulkarni, 2004. Randomized double-blind placebocontrolled trial to evaluate efficacy of ketodiet in predialytic chronic renal failure. Journal of Renal Nutrition, 14: 89-96.

Salem L and B Harvie, 2016. Biochemistry and Haematology. Pathology for Renal Nurses, pp. 1-2.

Vijaya KL, M Aruna, SVLN Rao and P RamaMohan, 2019. Dietary counseling by renal dietician improves the nutritional status of hemodialysis patients. Indian J. Nephrol., 29: 179-185. 